\title{
The Development of a Local Ground Motion Prediction Equation from Recorded Data
}

\author{
Lubna Obaid ${ }^{1}$, Sama Alani ${ }^{1}$, Maher Omar ${ }^{1}$, Samer Barakat $^{1}$, Mohamed Arab ${ }^{1}$, Moussa Leblouba ${ }^{1}$, \\ Abdallah Shanableh ${ }^{1}$, Ali Tahmaz ${ }^{1}$ \\ ${ }^{1}$ Department of Civil and Environmental Engineering, University of Sharjah, \\ Sharjah, United Arab Emirates \\ lobaid@sharjah.ac.ae; salani@sharjah.ac.ae; momar@sharjah.ac.ae; sbarakat@sharjah.ac.ae; marab@sharjah.ac.ae; \\ mleblouba@sharjah.ac.ae; shanableh@sharjah.ac.ae; atahmaz@sharjah.ac.ae
}

\begin{abstract}
A representative attenuation relationship is one of the key components required in seismic hazard assessment of a region of interest. In this project, a ground-motion attenuation relationship for peak ground acceleration was developed for Sharjah, United Arab Emirates (UAE) region. Incorporated Research Institutions for Seismology (IRIS) as well as Building and Housing Research Center (BHRC) databases were utilized to collect strong ground motion of 90 horizontal component waveforms from different earthquakes measured by 440 stations in Iran and Sharjah. The collected dataset is composed from earthquakes that occurred in Iran with attenuation reaching UAE in moment magnitude varying from 4 to 7.3. The relationships derived are for distances up to $100 \mathrm{~km}$, in a time period from 2008 to 2018. Attributes considered for each earthquake include earthquake date, time of occurrence, moment magnitude, depth, epicentral distance, acceleration time series, peak ground acceleration (PGA), and time shear velocity as well as event location and coordinates. A set of statistical analysis techniques was used to analyze and validate earthquake records. In this study, different attenuation relationship equations utilized for similar regions were collected from literature of previous work done in multiple countries. Based on the collected equations, new equations that are more suitable for Sharjah were developed by applying nonlinear regression analysis using Statistical Package for the Social Sciences (SPSS) statistics software and MATLAB. Accordingly, an optimum model was formulated that best suits Sharjah study area characteristics. The developed ground-motion prediction equations derived in the study can be used to predict earthquake-prone locations in UAE and other locations with similar characteristics. Additional artificial neural network (ANN) calculations were generated to verify the attenuated PGA mode in Sharjah based on Iranian attributes.
\end{abstract}

Keywords: Attenuation equation, ground-motion prediction, nonlinear regression, ANN, United Arab Emirate.

\section{Introduction}

Seismic waveforms through earthquakes are affected significantly while propagating from the local site and spreading upward. Strong ground-motion parameters can vary according to conditions. One of the most essential strong ground-motion parameters is denoted by acceleration records verified for each earthquake. Peak ground-acceleration (PGA) information is critical for earthquake risk assessments and crisis response operations. Typically, earthquake hazard assessment is done by means of an earthquake ground-motion attenuation relationship or ground-motion prediction equation (GMPE). It provides the estimation of ground motion for an earthquake of a given magnitude at different distances through a curve fitted to observed data by the development of an attenuation relationship from recorded seismic events [1][2].

In order to estimate PGA, earthquake data were collected over the last decade. Many attenuation relationships were established using different statistical regression techniques by studying the association between acceleration values from several sources and site conditions. Collected records contain information about earthquake size, location to source distance, site conditions, earthquake depth, and faulting mechanism. Moreover, the time average shear-wave velocity $\left(\mathrm{V}_{\mathrm{S} 30}\right)$ is a frequently used parameter to represent the ground properties for seismic design. In this study, $\mathrm{V}_{\mathrm{S} 30}$ was used to examine soil characteristics of the stations [2][3]. Table 1 summarizes some of the earthquake GMPE developed in the last decade.

The structure of the presented research is outlined as follows. Data collected for earthquakes that occurred in Iran and attenuated to Sharjah will be presented. Different ground-motion prediction equations developed in previous research for similar regions will be discussed. Accordingly, the collected data of Iran will be passed through all the equations using nonlinear regression techniques (using SPSS programs) to obtain a response for Sharjah with data that are near the actual records at Sharjah recording stations. Furthermore, an artificial neural network (ANN) model to predict the PGA for Sharjah 
will be generated using the MATLAB machine learning toolbox. Lastly, a comparison between the developed models will be done, and suggestions and recommendations for future research will be discussed.

Table 1: Ground-motion prediction equations used in literature and their specifications.

\begin{tabular}{|c|c|c|c|c|c|c|}
\hline Ref. & $\begin{array}{l}\text { Epicenter } \\
\text { location }\end{array}$ & $\begin{array}{l}\text { Time } \\
\text { Period }\end{array}$ & Calculated & No. of Records & $\begin{array}{l}\text { Moment } \\
\text { Magnitude } \\
\text { (MW) }\end{array}$ & $\begin{array}{l}\text { Depth } \\
\text { R(km) }\end{array}$ \\
\hline [1] & Turkey & $\begin{array}{l}1999 \text { to } \\
2006\end{array}$ & PGA & 402 records & $>4.0$ & $4.9-18.5$ \\
\hline [2] & Iran & N/A & $\begin{array}{l}\text { PGA, PSA for } 5 \% \text { of } \\
\text { damping. }\end{array}$ & Simulated Records & $5.0-7.5$ & $5-200$ \\
\hline$[3]$ & Iran & $\begin{array}{l}1978 \text { to } \\
2008\end{array}$ & $\begin{array}{l}\text { PGA, PSA in terms } \\
\text { of } g\end{array}$ & $\begin{array}{l}258 \text { records from } 109 \\
\text { Earthquakes } \\
\text { Simulated Records }\end{array}$ & $5.0-7.4$ & Up to 100 \\
\hline [4] & Malaysia & $\begin{array}{l}2004 \text { to } \\
2012\end{array}$ & $\begin{array}{c}\text { PGA in gals for } \\
\text { subduction mechanism }\end{array}$ & $\begin{array}{l}130 \text { total records from } \\
7 \text { earthquakes }\end{array}$ & $/ 3.5$ & Up to 100 \\
\hline [5] & China & N/A & $\begin{array}{c}\text { GMPE by } \\
\text { heterogeneous } \\
\text { Bayesian Learning }\end{array}$ & $\begin{array}{c}132 \text { records from } 29 \\
\text { stations }\end{array}$ & $>4.0$ & $\begin{array}{l}\text { Up to } \\
1000\end{array}$ \\
\hline [6] & USA & N/A & $\begin{array}{l}\text { GMPE by using the } \\
\text { ambient seismic field }\end{array}$ & Simulated Virtual Records & $5.0-7.0$ & N/A \\
\hline [7] & USA & N/A & $\begin{array}{c}\text { (PGA, PGV \& PSA at } \\
0.3 \text { and } 1 \mathrm{~s})\end{array}$ & $\begin{array}{l}188 \text { Earthquakes simulated } \\
\text { records }\end{array}$ & $3.0-5.0$ & Up to 200 \\
\hline$[8]$ & Italy & $\begin{array}{l}1972 \text { to } \\
2007\end{array}$ & $\begin{array}{c}\text { PGA, PGV and } \\
5 \% \text { damped PSA. }\end{array}$ & $\begin{array}{l}561 \text { three-component } \\
\text { waveforms from } 107 \\
\text { earthquakes }\end{array}$ & $4.0-6.9$ & Up to 100 \\
\hline [9] & N/A & N/A & $\begin{array}{l}\text { GMPE developed for } \\
\text { inelastic response } \\
\text { spectra }\end{array}$ & $\begin{array}{l}\text { Over 3,100 from } 64 \\
\text { earthquakes }\end{array}$ & $4.3-7.9$ & Up to 200 \\
\hline [10] & Italy & N/A & $\begin{array}{l}\text { GMPEs for PGA, } \\
\text { PGV, PSA }\end{array}$ & $\begin{array}{c}1213 \text { recordings from } 218 \\
\text { earthquakes }\end{array}$ & $4.0-6.9$ & Up to 200 \\
\hline [11] & Indonesia & $\begin{array}{l}2000 \text { to } \\
2007\end{array}$ & PGA, PGV \& PSA & 12 Earthquakes & $5.0-9.0$ & $\begin{array}{l}200- \\
1500\end{array}$ \\
\hline [12] & Bangladesh & $\begin{array}{c}1885 \text { to } \\
1999\end{array}$ & $\begin{array}{c}\text { Attenuation } \\
\text { earthquake intensity } \\
\text { equations }\end{array}$ & 7 Earthquakes & $5.1-8.1$ & up to 300 \\
\hline [13] & Turkey & $\begin{array}{l}1976 \text { to } \\
2004\end{array}$ & $\begin{array}{l}\text { PGA depending on } \\
\text { rock site and soil site } \\
\text { data }\end{array}$ & 516 earthquakes & $>=4.0$ & Up to 200 \\
\hline [14] & Iran & N/A & $\begin{array}{c}\text { Five regional } \\
\text { earthquake prediction } \\
\text { models }\end{array}$ & $\begin{array}{c}37 \text { records from } 35 \\
\text { earthquakes }\end{array}$ & $4.0-7.0$ & Up to 150 \\
\hline [15] & Malaysia & $\begin{array}{l}2004 \text { to } \\
2012\end{array}$ & PGA for earthquake & $\begin{array}{l}\text { More than } 150 \text { records } \\
\text { from } 9 \text { earthquakes }\end{array}$ & $>=3.5$ & N/A \\
\hline [16] & Iran & $\begin{array}{l}1978 \text { to } \\
2012\end{array}$ & $\begin{array}{c}\text { GMPE for 5\%- } \\
\text { damped PSAGMPE }\end{array}$ & 200 earthquakes & $5.0-7.4$ & Up to 100 \\
\hline [17] & Iran & $\begin{array}{l}\text { Up to } \\
2004\end{array}$ & $\begin{array}{l}\text { PGA, PGV, and EPA } \\
\text { parameters }\end{array}$ & $\begin{array}{l}89 \text { earthquake events } \\
\text { including } 307 \text { earthquake } \\
\text { records }\end{array}$ & $4.5-7.5$ & Up to 150 \\
\hline [18] & Iran & $\begin{array}{c}1975 \text { to } \\
1995\end{array}$ & $\begin{array}{l}\text { PGH and PGV in three } \\
\text { cases of site conditions }\end{array}$ & $\begin{array}{c}279 \text { entries from about } 30 \\
\text { areas }\end{array}$ & $3.0-7.4$ & Up to 100 \\
\hline
\end{tabular}

* PGA: peak ground acceleration; PGV: peak ground velocity; GMPE: Ground-motion prediction equation; PSA: pseudo spectral acceleration for spectral periods; EPA: effective peak acceleration. 


\section{Strong Motion Database}

A total of 90 high ground-motion data in the study period of the last 10 years (from 2008 till 2018) were assessed as shown in Figure 1. The earthquake sources were Iran and each showed attenuation to United Arab Emirates (UAE). Iranian and UAE data were obtained from the Housing and Urban Development Research Centre (BHRC) and Incorporated Research Institutions for Seismology (IRIS) databases, respectively. With respect to the focal depth, shallow earthquakes with a threshold of $100 \mathrm{~km}$ were considered with moment magnitude of database ranges between 4.0 and 7.3.

Earthquake source information was collected by 31 different stations in Iran, while the corresponding attenuated signal was measured in University of Sharjah, Sharjah station (UOSS) with coordinates of $56.20^{\circ}$ longitude and $24.95^{\circ}$ latitude. Regression analyses were done for 90 time series records; 50 of these time series records occurred on rocks $\left(V_{\mathrm{S} 30}>750 \mathrm{~m} / \mathrm{s}\right)$, 35 occurred on stiff soil $\left(360<\mathrm{V}_{\mathrm{S} 30} \leq 750 \mathrm{~m} / \mathrm{s}\right)$, and the rest $\left(180<\mathrm{V}_{\mathrm{S} 30}<=360 \mathrm{~m} / \mathrm{s}\right)$ occurred on soft soil. Table 2 shows a sample of the collected data from Iran station with their characteristics with the corresponding peak ground horizontal acceleration (PGH) collected from Sharjah Station.

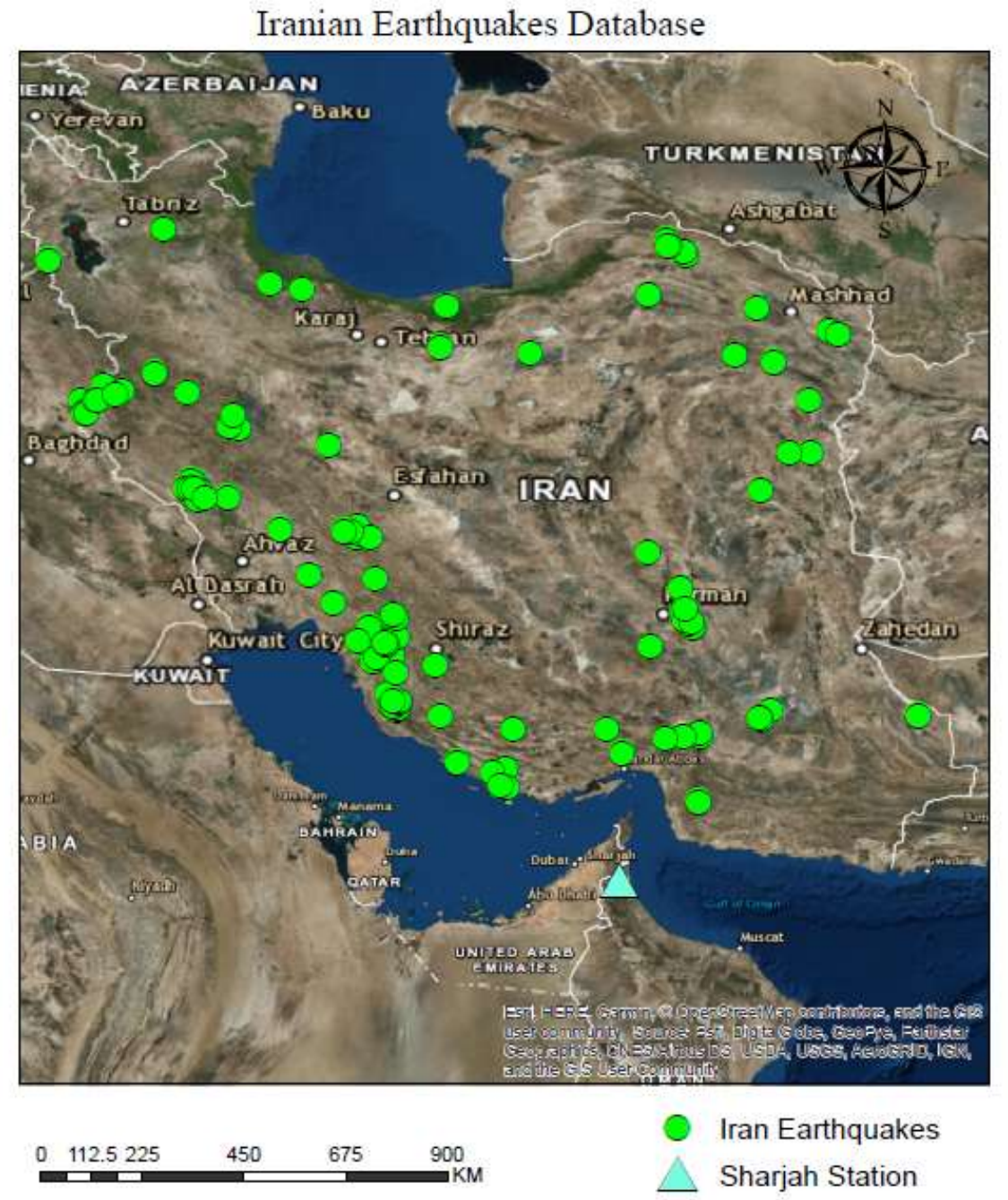

Fig. 1: Geographic distribution of the selected events and recording stations. 
Table 2: Characteristics of selected records.

\begin{tabular}{|c|c|c|c|c|c|c|c|c|c|c|}
\hline Date & Time & & Lat. & Long. & $\begin{array}{l}\text { Epicenter } \\
\text { Distance }\end{array}$ & $\begin{array}{c}\text { Moment } \\
\text { Magnitude }\end{array}$ & $\begin{array}{c}\text { Depth } \\
(\mathbf{k m})\end{array}$ & $\begin{array}{l}\text { Effective } \\
\text { Duration }\end{array}$ & $V_{S 30}(\mathrm{~m} / \mathrm{s})$ & $\begin{array}{c}\text { Actual PGH in } \\
\text { Sharjah }\end{array}$ \\
\hline $5 / 26 / 2009$ & $11: 52: 48$ & PM & 33.94 & 48.6 & 19 & 4.6 & 22 & 2.17 & 891 & 0.442 \\
\hline $10 / 13 / 2009$ & $12: 54: 27$ & $\mathrm{AM}$ & 35.05 & 46.93 & 70 & 5.1 & 10 & 14.15 & 514 & 0.526 \\
\hline $2 / 23 / 2010$ & $10: 25: 54$ & AM & 32.57 & 48.38 & 16 & 5.4 & 16 & 5.46 & 582 & 0.691 \\
\hline $7 / 20 / 2010$ & $7: 38: 10$ & $\mathrm{PM}$ & 27.16 & 53.92 & 49 & 5.9 & 18 & 15.13 & 567 & 13.105 \\
\hline $7 / 30 / 2010$ & $1: 50: 14$ & $\mathrm{PM}$ & 35.28 & 59.26 & 52 & 5.9 & 20 & 21.29 & 1196 & 0.995 \\
\hline $7 / 31 / 2010$ & $6: 52: 59$ & $\mathrm{AM}$ & 29.6 & 56.79 & 66 & 5.7 & 14 & 23.18 & 516 & 0.738 \\
\hline $8 / 27 / 2010$ & $7: 23: 48$ & $\mathrm{PM}$ & 35.45 & 54.4 & 17 & 5.6 & 7 & 3.88 & 759 & 0.814 \\
\hline $9 / 27 / 2010$ & $11: 22: 46$ & $\mathrm{AM}$ & 29.78 & 51.76 & 45 & 5.8 & 18 & 20.98 & 450 & 0.137 \\
\hline $1 / 5 / 2011$ & $5: 55: 47$ & AM & 30.16 & 51.7 & 15 & 4.6 & 16 & 2.58 & 1262 & 0.703 \\
\hline $1 / 5 / 2011$ & $4: 32: 21$ & PM & 30.18 & 51.66 & 15 & 4.5 & 16 & 2.94 & 1262 & 0.493 \\
\hline $1 / 5 / 2011$ & $5: 50: 53$ & PM & 30.19 & 51.66 & 39 & 5 & 20 & 18.43 & 617 & 0.591 \\
\hline $1 / 7 / 2011$ & $11: 52: 59$ & PM & 30.17 & 51.74 & 16 & 5.2 & 20 & 5.25 & 1262 & 0.522 \\
\hline $6 / 15 / 2011$ & $1: 05: 30$ & AM & 27.8 & 57.79 & 11 & 4.9 & 16 & 3.77 & 776 & 4.032 \\
\hline $6 / 26 / 2011$ & $7: 47: 00$ & PM & 30.03 & 57.58 & 31 & 5.2 & 22 & 12.97 & 604 & 3.870 \\
\hline $7 / 26 / 2011$ & $4: 04: 12$ & $\mathrm{AM}$ & 36.61 & 56.76 & 18 & 4.9 & 18 & 18.16 & 155 & 4.020 \\
\hline $1 / 11 / 2012$ & $5: 08: 00$ & PM & 36.38 & 52.74 & 39 & 5.2 & 16 & 17.86 & 514 & 3.089 \\
\hline $2 / 5 / 2012$ & $6: 10: 40$ & $\mathrm{AM}$ & 28.66 & 51.56 & 23 & 5 & 18 & 11.62 & 853 & 3.540 \\
\hline $3 / 18 / 2012$ & $2: 38: 15$ & AM & 36.83 & 49.22 & 17 & 5.5 & 10 & 4.76 & 898 & 2.806 \\
\hline $5 / 3 / 2012$ & 10:09:37 & $\mathrm{AM}$ & 32.88 & 47.72 & 10 & 4.8 & 12 & 2.46 & 1564 & 3.135 \\
\hline $5 / 14 / 2012$ & $10: 12: 35$ & $\mathrm{AM}$ & 27.88 & 57.78 & 8 & 4.4 & 4 & 1.67 & 894 & 3.166 \\
\hline $7 / 1 / 2012$ & $2: 49: 46$ & AM & 31.76 & 50.98 & 30 & 5.2 & 16 & 9.57 & 643 & 3.124 \\
\hline $7 / 1 / 2012$ & $10: 01: 26$ & $\mathrm{PM}$ & 34.5 & 59.95 & 16 & 4.4 & 14 & 2.6 & 1477 & 0.004 \\
\hline $7 / 24 / 2012$ & $6: 56: 36$ & AM & 31.77 & 50.93 & 18 & 4.9 & 16 & 4.14 & 919 & 4.230 \\
\hline $9 / 2 / 2012$ & $12: 50: 02$ & $\mathrm{AM}$ & 33.44 & 59.99 & 20 & 5.4 & 18 & 4.51 & 1397 & 2.622 \\
\hline $12 / 5 / 2012$ & 5:08:11 & PM & 33.44 & 59.56 & 15 & 5.6 & 32 & 10.92 & 398 & 3.057 \\
\hline
\end{tabular}




\section{Development of Regional Attenuation Equation}

The main purpose of this study was to derive a regional earthquake attenuation equation for Sharjah, UAE. Based on this objective, several equations were reviewed in recent literature with respect to locations with similar characteristics. The eight selected equations are discussed in Table 3.

Table 3: Selected equations as a basis for nonlinear regression analysis.

\begin{tabular}{|c|c|c|c|c|c|}
\hline Ref. & Period & Mag. & $\begin{array}{c}\text { Depth } \\
(\mathbf{k m})\end{array}$ & Location & Equation Used \\
\hline [19] & $\begin{array}{l}1973- \\
2004\end{array}$ & $\begin{array}{l}4.5 \text { to } \\
7.5\end{array}$ & Up to 30 & UAE & $\log _{10}(y)=C_{1}+C_{2} M+C_{4} \log _{10}(r)+C_{A} S_{A}+C_{S} S_{S}$ \\
\hline [20] & $\begin{array}{l}1902- \\
2004\end{array}$ & $\begin{array}{l}5.0 \text { to } \\
7.7\end{array}$ & $\begin{array}{l}\text { Up to } \\
100\end{array}$ & UAE & $\log P G A=a+b(M-6)+c(M-6)^{2}+k r+d \times \log (r)+s$ \\
\hline [1] & $\begin{array}{l}1999- \\
2006\end{array}$ & $\begin{array}{c}\text { Greater } \\
\text { than } \\
4.0\end{array}$ & $\begin{array}{l}\text { Up to } \\
344\end{array}$ & Turkey & $\ln P G A=b_{1}+b_{2}(M-6)+b_{3}(M-6)^{2}+b_{5} \ln r+b_{v} \ln \frac{V_{S 30}}{V_{r e f}}$ \\
\hline [2] & N/A & $\begin{array}{l}5.0,6.0 \\
\text { and } 7.0\end{array}$ & $\begin{array}{l}\text { Up to } \\
100\end{array}$ & Iran & $\ln A(f)=c_{1}(f)+c_{2}(f) M+c_{3}(f) \ln R+c_{4}(f) R+\varepsilon$ \\
\hline [21] & N/A & $\begin{array}{l}5.0 \text { to } \\
7.4\end{array}$ & $\begin{array}{l}\text { Up to } \\
100\end{array}$ & Iran & $\log Y=a+b\left(M_{w}-6\right)+c\left(M_{w}-6\right)^{2}+d\left(r_{i b}^{2}+h^{2}\right)^{\overline{2}}+\sigma$ \\
\hline [17] & $\begin{array}{l}1975- \\
2004\end{array}$ & $\begin{array}{l}4.5 \text { to } \\
7.5\end{array}$ & 5 to 150 & Iran & $\ln y=\mathrm{C}_{1}+\mathrm{C}_{2} \mathrm{Ms}+\mathrm{C}_{3} \ln \left[\mathrm{R}+\mathrm{C}_{4} \exp [\mathrm{Ms}]\right]+\mathrm{C}_{5} \mathrm{R}$ \\
\hline [18] & N/A & $\begin{array}{l}3.0 \text { to } \\
7.4\end{array}$ & $\begin{array}{l}\text { Up to } \\
100\end{array}$ & Iran & $\operatorname{Ln} \cdot(A)=C_{1}+C_{2} \times(M-6)+C_{3} \operatorname{Ln}\left(\operatorname{sqrt}\left(E^{2} D^{2}+h^{2}\right)\right)$ \\
\hline [22] & N/A & $\begin{array}{l}4.0 \text { to } \\
7.5\end{array}$ & $\begin{array}{l}\text { Up to } \\
200\end{array}$ & Europe & $\log (y)=C_{1}+C_{2} M+C_{3} r+C_{4} \log (r)+\sigma P$ \\
\hline
\end{tabular}

\section{Results and Discussion}

\subsection{Regression Results}

In the present study, the summarized equations and their coefficients serve as a basis for regression analysis. The analysis of variance (ANOVA) technique used to distinguish between different regression results is shown in the following eight equations, using the same previously discussed variables:

$$
\begin{gathered}
\log _{10}(\mathrm{y})=0.115+0.206 \mathrm{M}+-0.430 \log _{10}(\mathrm{r})+0.011 \mathrm{~S}_{\mathrm{A}}+0.463 \mathrm{~S}_{\mathrm{S}} \\
\operatorname{LogPGA}=1.17+0.670(\mathrm{M}-6)+0.325(\mathrm{M} 1-6)^{2}+-0.011 \mathrm{r}+-0.036 \times \log (\mathrm{r}) \\
\ln \mathrm{PGA}=3.56+0.16(\mathrm{M}-6)-0.0052(\mathrm{M}-6)^{2}-0.658 \ln \mathrm{r}-0.701 \ln \frac{\mathrm{V}_{\mathrm{S} 30}}{\mathrm{~V}_{\mathrm{ref}}} \\
\ln \mathrm{A}(\mathrm{f})=3.562(\mathrm{f})+0.072(\mathrm{f}) \mathrm{M}-0.914(\mathrm{f}) \ln \mathrm{R}+0.0105(\mathrm{f}) \mathrm{R}+\varepsilon \\
\log \mathrm{Y}=1.198+0.704\left(\mathrm{M}_{\mathrm{w}}-6\right)+0.358\left(\mathrm{M}_{\mathrm{w}}-6\right)^{2} \pm 0.0115\left(\mathrm{r}_{\mathrm{jb}}^{2}+\mathrm{h}^{2}\right)^{\frac{1}{2}}+\sigma \\
\ln \mathrm{y}=1.209+0.17 \mathrm{Ms}+-0.275 \ln [\mathrm{R}+-0.051 \exp [\mathrm{Ms}]]+0.002 \mathrm{R} \\
\operatorname{Ln}(\mathrm{A})=3.678+0.2 \times(\mathrm{M}-6)+-0.662 \operatorname{Ln}\left(\operatorname{sqrt}\left(\mathrm{EPD}^{2}+\mathrm{h}^{2}\right)\right) \\
\log (\mathrm{y})=1.365-0.00254 \mathrm{M}+0.002 \mathrm{r}-0.638 \log (\mathrm{r})+\sigma \mathrm{P}
\end{gathered}
$$


Statistical analysis was carried out on the modified equations, and equations confidence intervals have been obtained, considering Sharjah station accelerogram data as true values. Equation 3 showed the most accurate results, comparing to the true value in UOSS database, while the worst equation in prediction of peak ground accelerations was Equation 6. The difference in predictions refers to the different factor considerations and the type of computation in each equation compared to the others. Nonlinear regression results are illustrated in Figure 2.

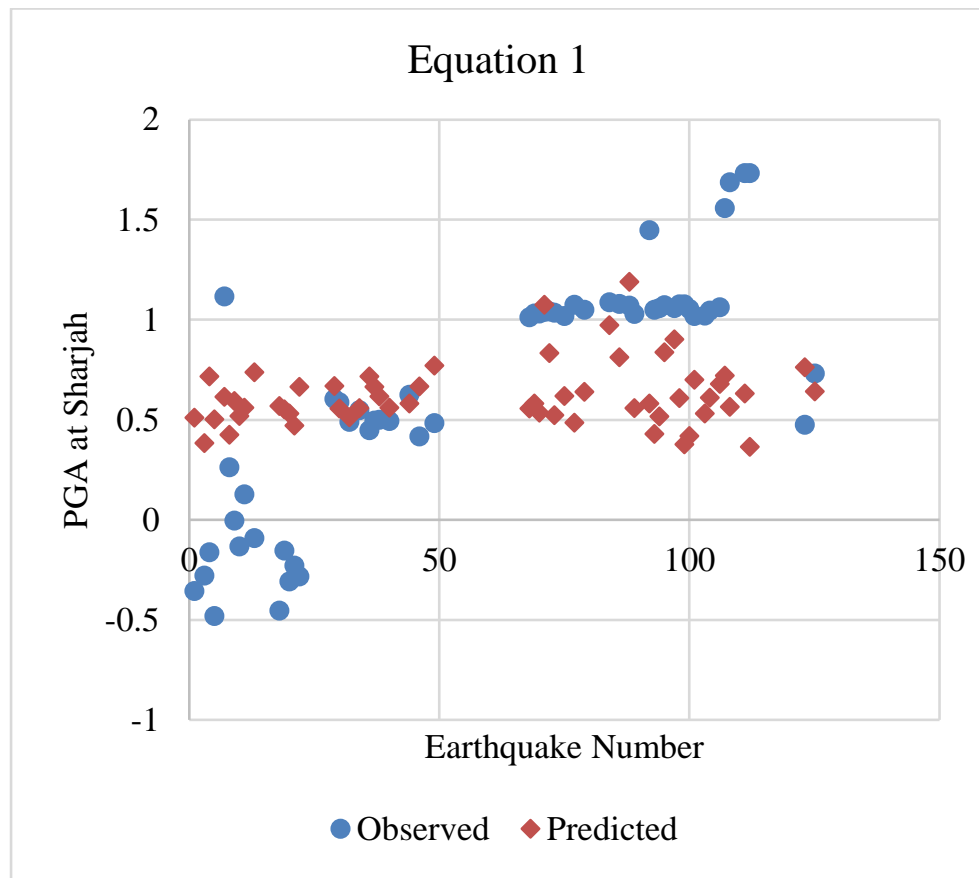

a) Modified equation 1 predicted PGA versus observed

Equation 3

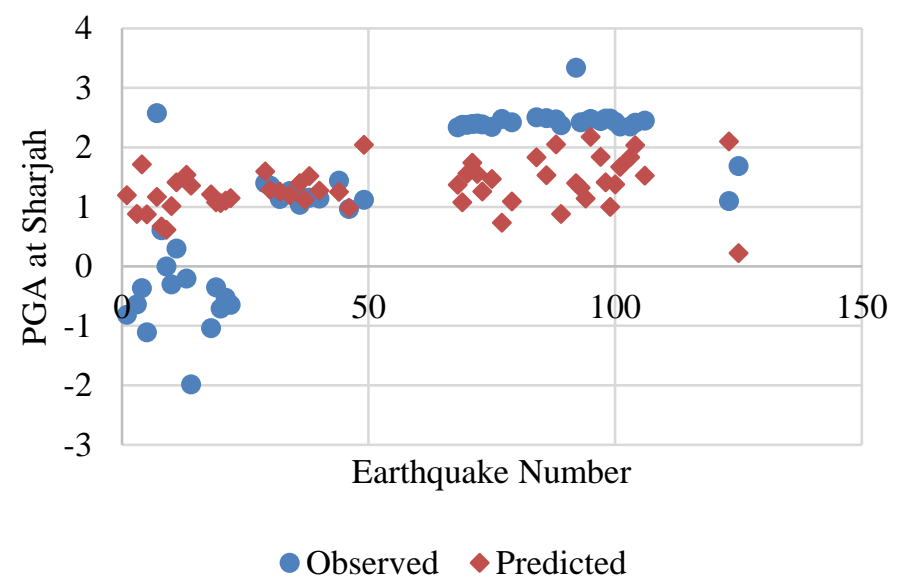

c) Modified equation 3 predicted PGA versus observed

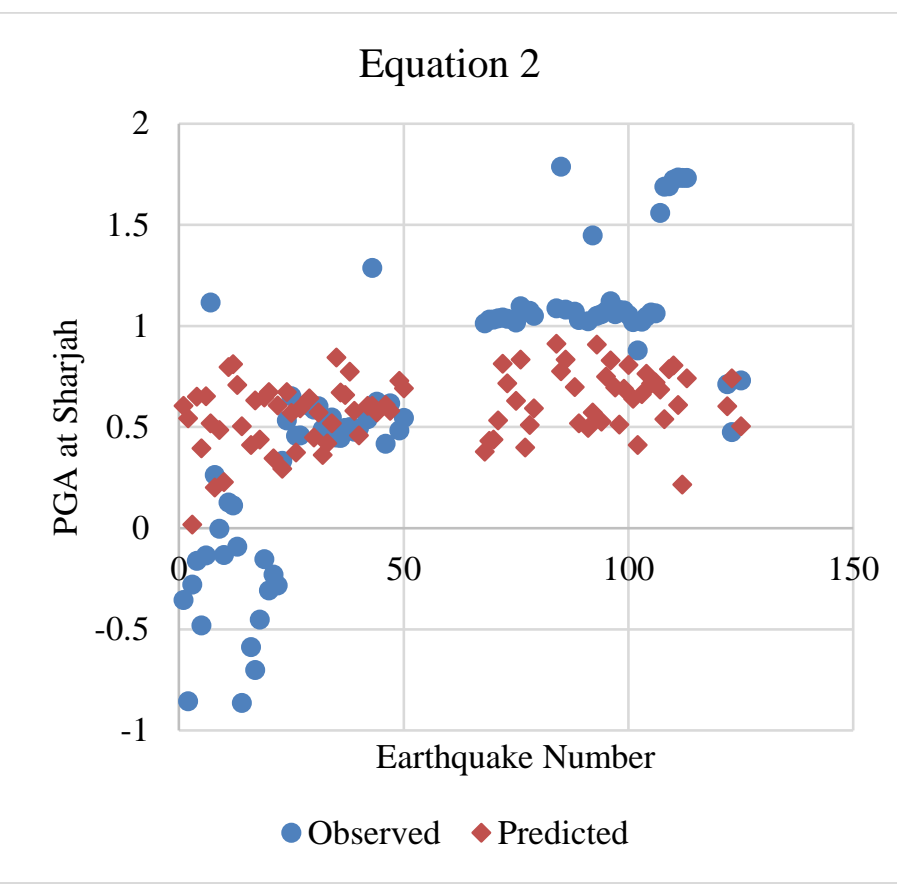

b) Modified equation 2 predicted PGA versus observed

Equation 4

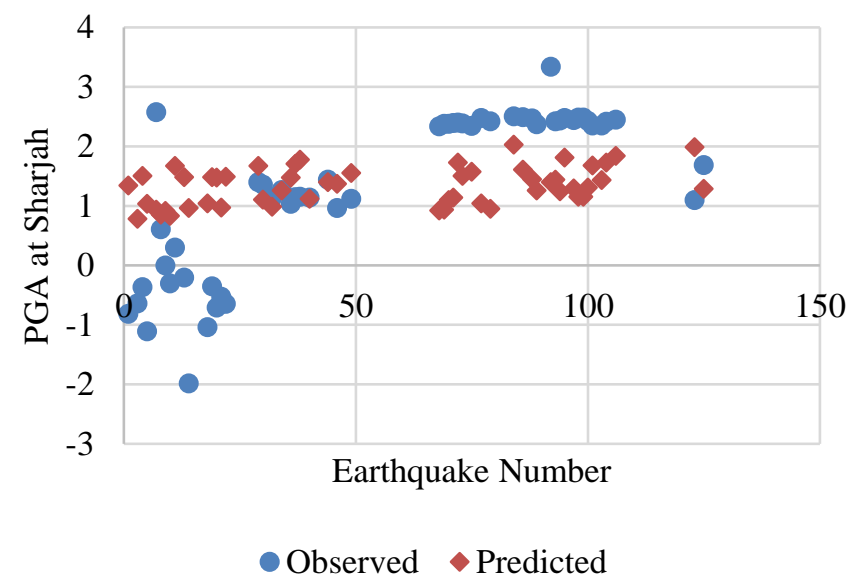

d) Modified equation 4 predicted PGA versus observed 


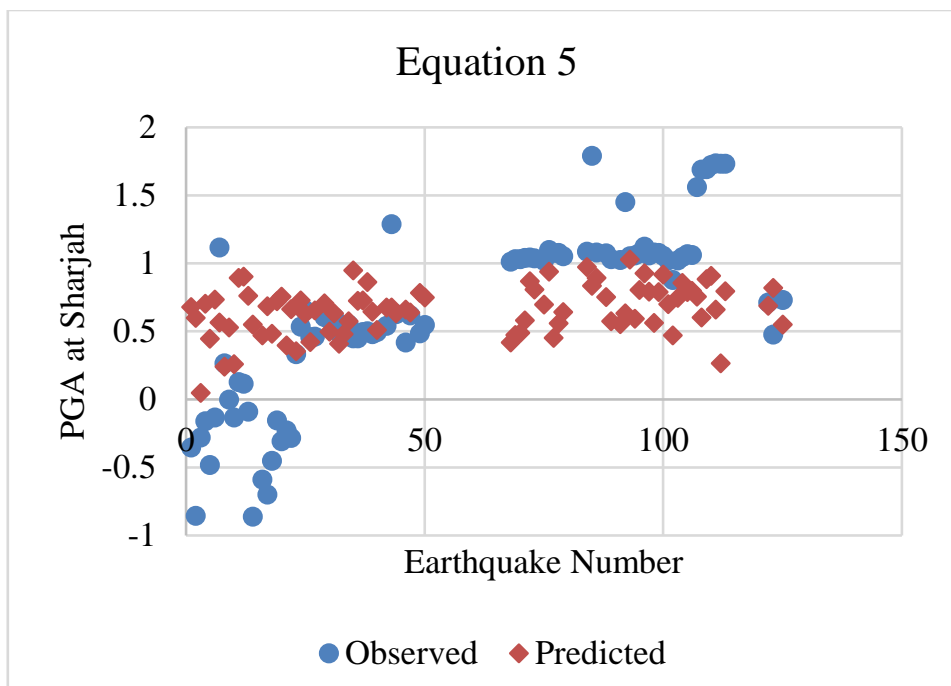

e) Modified equation 5 predicted PGA versus observed

\section{Equation 7}

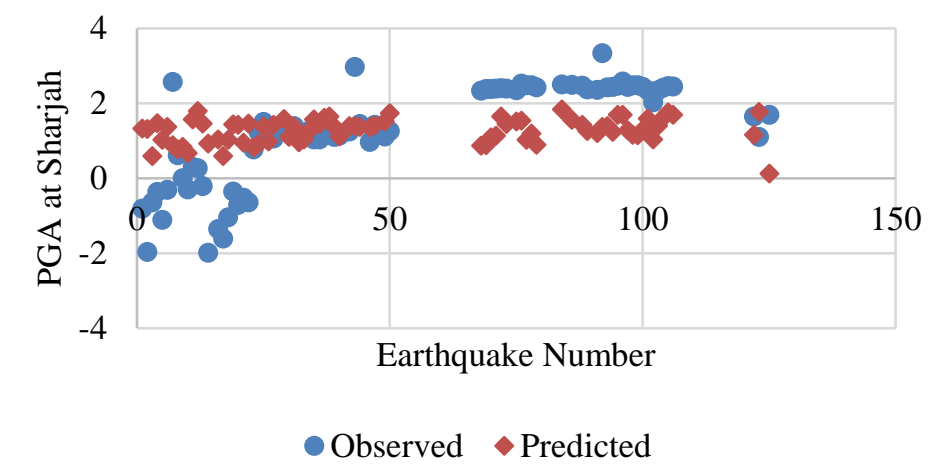

g) Modified equation 7 predicted PGA versus observed

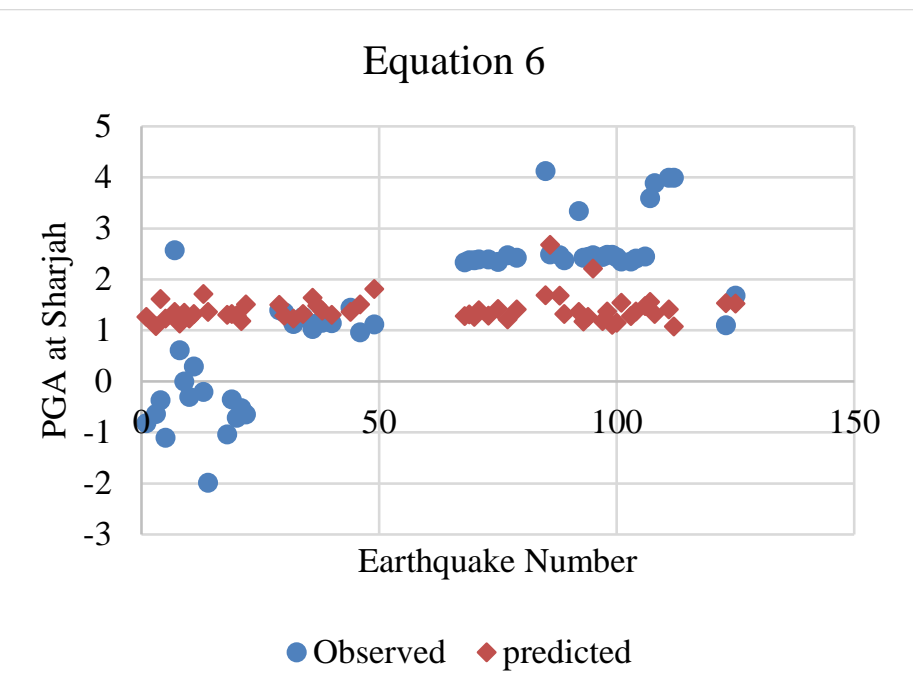

f) Modified equation 6 predicted PGA versus observed

\section{Equation 8}

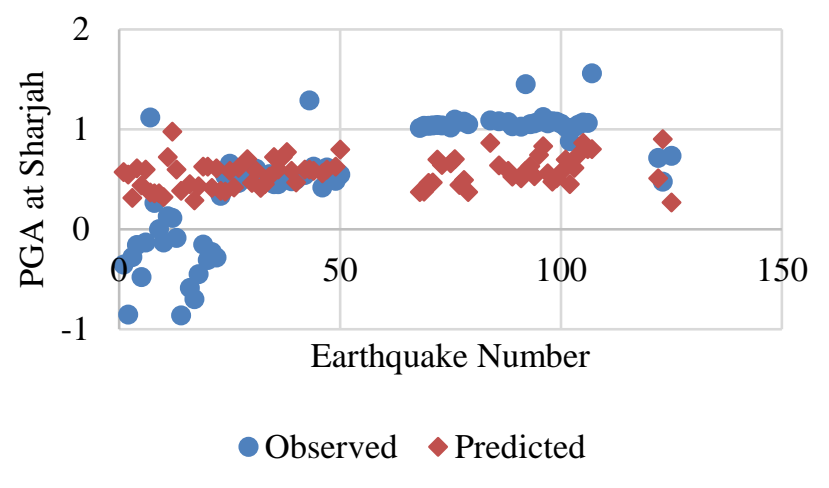

h) Modified equation 8 predicted PGA versus observed

Fig. 2: Summary of the obtained results by the modified equations.

Accordingly, the obtained data were combined in one graph as shown in Figure 3, then used to formulate equation 9. Equation 9 is an optimal equation that can be utilized in predicting earthquakes at Sharjah, UAE, based on multiple factors and experience derived from literature and analysis. Figure 4 shows the results obtained by using equation 9 . 


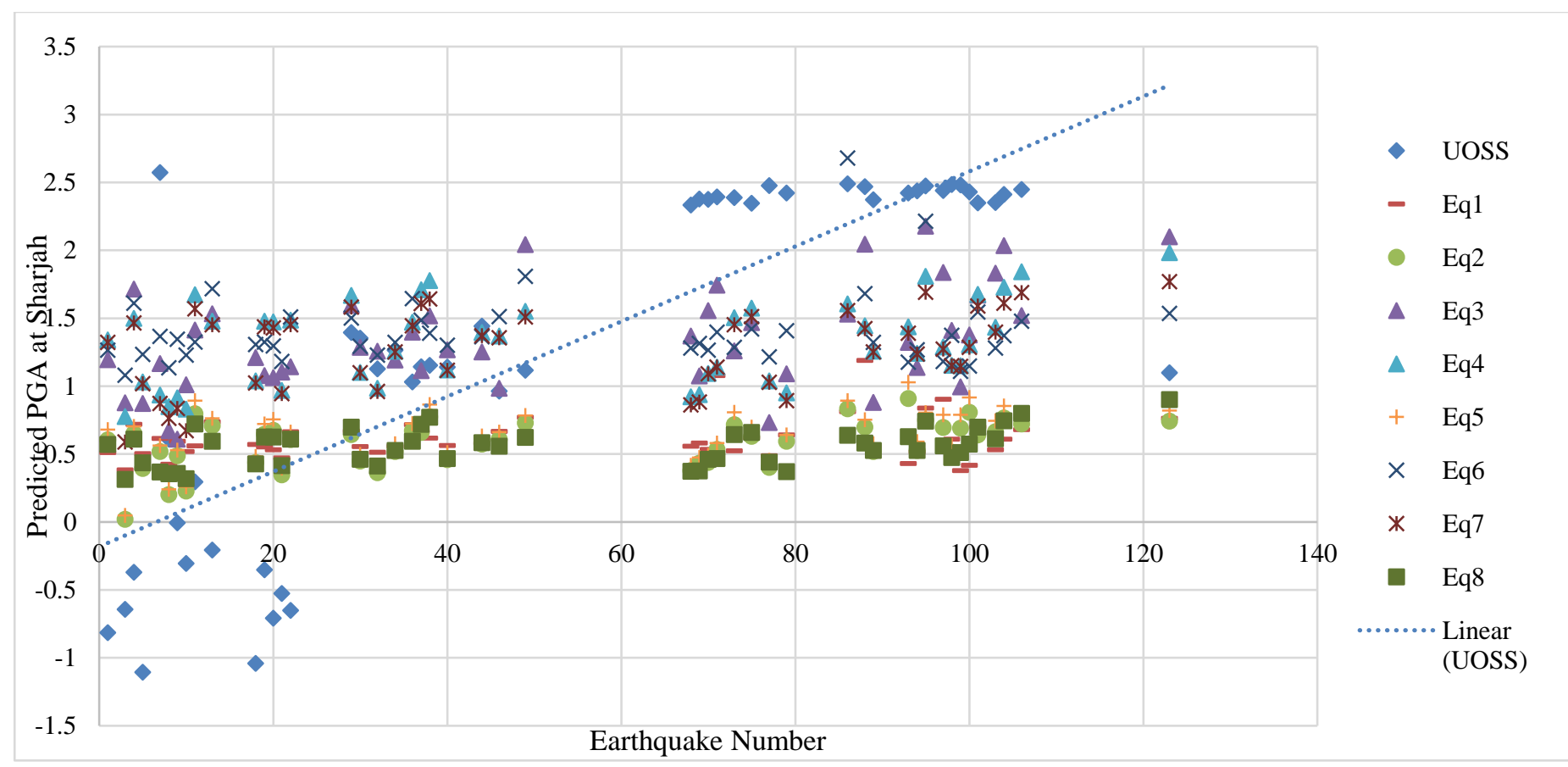

Fig. 3: Final modeled equation results.

Final formulated equation

$$
\operatorname{lnPGA}=0.262+2.681 \times\left(\mathrm{M}_{\mathrm{W}}-6\right)+1.247 \times\left(\mathrm{M}_{\mathrm{W}}-6\right)^{2}+2.88 \times \log \mathrm{r}+0.069 \times \mathrm{r}-0.93 \times \ln \frac{\mathrm{V}_{\mathrm{S} 30}}{\mathrm{~V}_{\text {ref }}}
$$

Where, $\mathrm{M}_{\mathrm{W}}$ is the moment magnitude; $\mathrm{r}$ is the hypocenter distance from earthquake position to the earthquake location; $V_{S 30}$ is the time-averaged shear wave velocity in the top $30 \mathrm{~m}$ of the site; and $V_{\text {ref }}$ is a reference velocity $=760 \mathrm{~m} / \mathrm{s}$ corresponding to the National Earthquake Hazards Reduction Program (NEHRP).

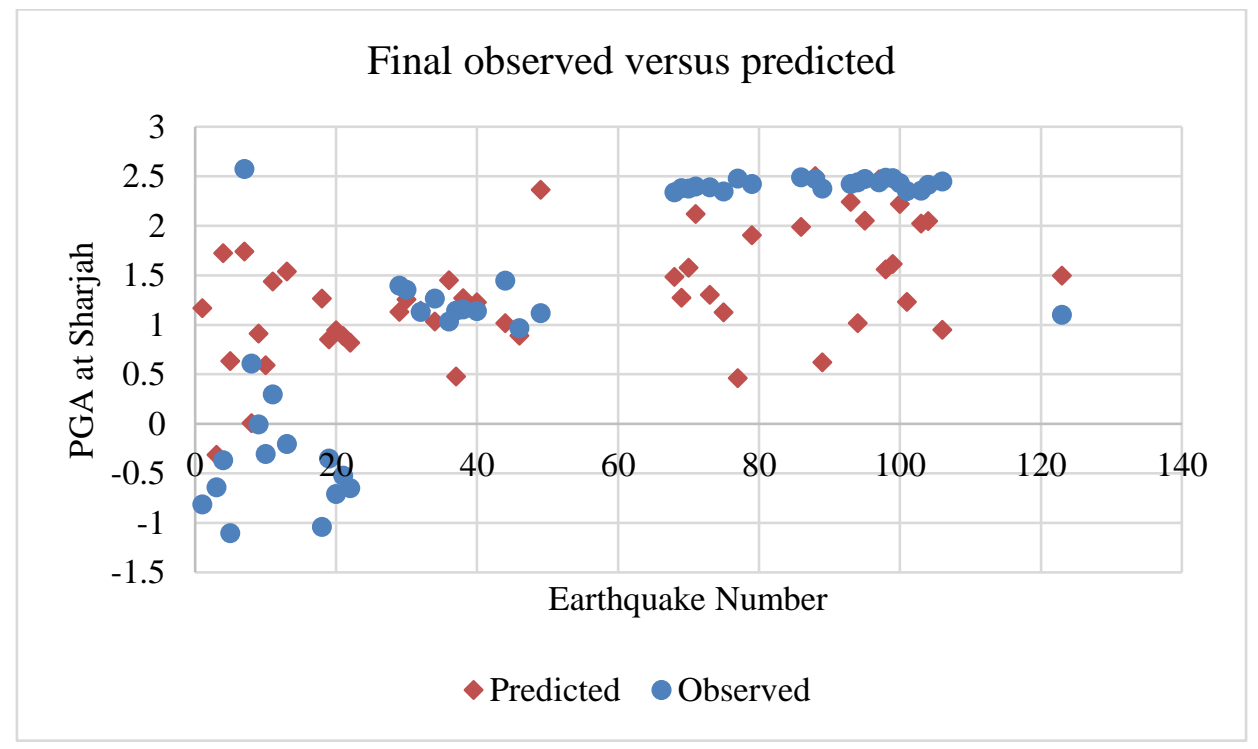

Fig. 4: Final modeled equation results. 


\subsection{Artificial Neural Network (ANN) Results}

An artificial neural network was built to learn, model, and then validate findings. Figure 5 shows the ANN, which indicates high accuracy networking; the training and validation data have reached higher accuracy results than would have been obtained in normal regression methods. These results identify a more accurate result to be predicted. Such a network can be advanced to further learning by adding new obtained data.

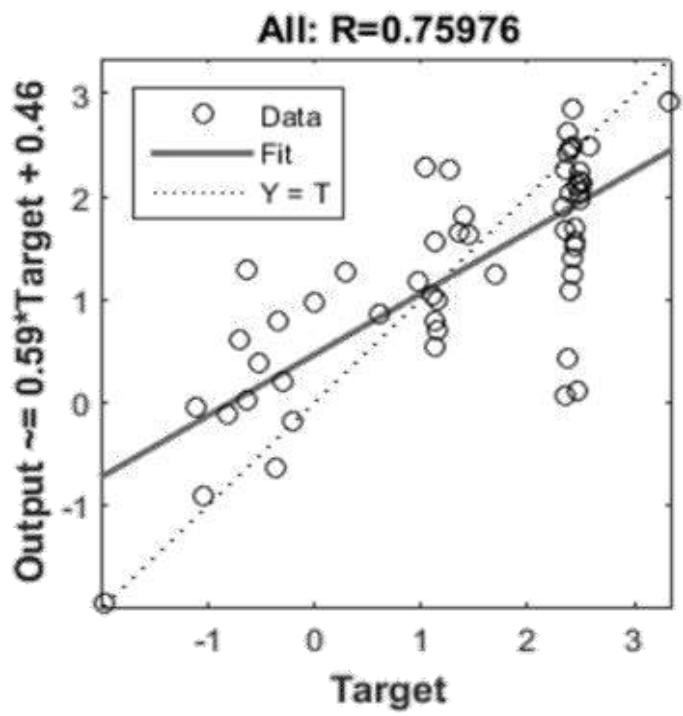

a) ANN fitting performance from MATLAB

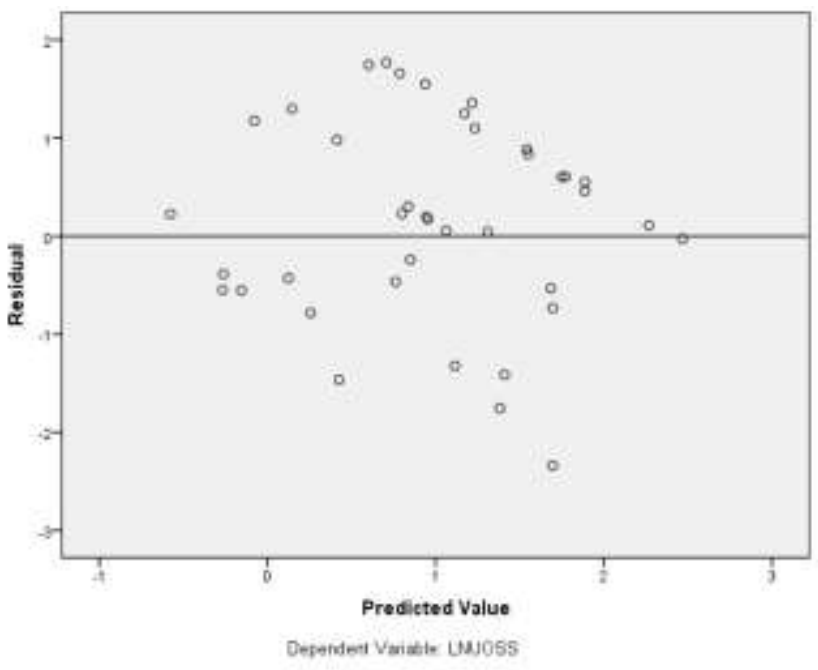

b) ANN fitting residuals using SPSS

Fig. 5: ANN model performance.

\section{Conclusion}

Simple descriptive statistical analyses were conducted to evaluate the collected earthquake data, and consequently minor modifications were made to improve prediction. Several peak ground-acceleration prediction equations were developed for the earthquakes attenuated to Sharjah in the UAE from large distances based on equations collected from the literature for locations with similar characteristics.

The developed equations were evaluated in terms of error sum of squares (SSE), mean squared error (MSE), and coefficient of determination $\left(\mathrm{R}^{2}\right)$ performance measures. Accordingly, a model was developed for predicting peak ground acceleration (PGA) for earthquakes that occur in Sharjah, UAE. The model took into consideration multiple parameters, namely: earthquake location, magnitude, depth, distance, and soil type. The developed model in this study is applicable for estimating PGA values for earthquakes where the following conditions apply: Moment magnitude: $4 \leq \mathrm{M}_{\mathrm{w}} \leq 7.3$, Hypocenter distance: $0 \leq \mathrm{R} \leq 100 \mathrm{~km}$, and $\mathrm{B}, \mathrm{C}, \mathrm{D}$, E soil classes (NEHRP).

The presented relationship was verified by an artificial neural network model for the purpose of predicting the PGA of earthquakes reaching the UAE as well as setting regulations and taking safety measures accordingly.

\section{Acknowledgment}

This research was supported by a targeted grant (1602040147-P) from the University of Sharjah. The authors are grateful for this support.

\section{References}

[1] A. Erken, G. Şengül Nomaler, and Z. Gündüz, "The development of attenuation relationship for Northwest Anatolia region," Arab. J. Geosci., vol. 11, no. 2, 2018.

[2] A. Yazdani, M. Kowsari, and S. Amani, "Development of a regional attenuation relationship for Alborz, Iran," $J$. Earth Sp. Phys., vol. 41, no. 4, pp. 39-50, 2016.

[3] M. Sharma et al., "Ground-motion prediction equations based on data from the Himalayan and Zagros regions," vol. 13, no. 8, pp. 1191-1210, 2009. 
[4] R. Mohd Noor, S. W. Ahmad, A. Adnan, and R. Nazir, "Attenuation function relationship of subduction mechanism and far field earthquake," ARPN J. Eng. Appl. Sci., vol. 11, no. 4, pp. 2597-2601, 2016.

[5] H. Q. Mu and K. V. Yuen, "Ground Motion Prediction Equation Development by Heterogeneous Bayesian Learning," Comput. Civ. Infrastruct. Eng., vol. 31, no. 10, pp. 761-776, 2016.

[6] G. C. B. M. A. Denolle, E. M. Dunham, G. A. Prieto, "Strong Ground Motion Prediction Using Virtual Earthquakes," Science (80-. ), vol. 343, no. 6169, pp. 399-404, 2014.

[7] B. Chiou, R. Youngs, N. Abrahamson, and K. Addo, "Ground-motion attenuation model for small-to-moderate shallow crustal earthquakes in California and its implications on regionalization of ground-motion prediction models," Earthq. Spectra, vol. 26, no. 4, pp. 907-926, 2010.

[8] D. Bindi, L. Luzi, M. Massa, and F. Pacor, "Horizontal and vertical ground motion prediction equations derived from the Italian Accelerometric Archive (ITACA)," Bull. Earthq. Eng., vol. 8, no. 5, pp. 1209-1230, 2010.

[9] Y. Bozorgnia, M. M. Hachem, and K. W. Campbell, "Ground motion prediction equation ("Attenuation Relationship') for inelastic response spectra," Earthq. Spectra, vol. 26, no. 1, pp. 1-23, 2010.

[10] D. Bindi et al., "Ground motion prediction equations derived from the Italian strong motion database," Bull. Earthq. Eng., vol. 9, no. 6, pp. 1899-1920, 2011.

[11] K. Megawati and and Tso-Chien Pan, "Ground-motion attenuation relationship for the Sumatran megathrust earthquakes," Earthq. Eng. Struct. Dyn., vol. 39, no. 8, pp. 827-845, 2010.

[12] M. S. Islam, M. M. Huda, M. N. Al-noman, and Al-hussaini, "Attenuation of Earthquake Intensity in Bangladesh," Proceedings, 3rd Int. Earthq. Symp. Bangladesh (IBES-3), Dhaka, pp. 481-488.

[13] K. Kayabali and T. Beyaz, "Strong motion attenuation relationship for Turkey-a different perspective," Bull. Eng. Geol. Environ., vol. 70, no. 3, pp. 467-481, 2011.

[14] A. M. Rajabi, M. Khamehchiyan, M. R. Mahdavifar, and V. Del Gaudio, "Attenuation relation of Arias intensity for Zagros Mountains region (Iran)," Soil Dyn. Earthq. Eng., vol. 30, no. 3, pp. 110-118, 2010.

[15] R. Nazir, H. Moayedi, R. B. M. Noor, and S. Ghareh, "Development of new attenuation equation for subduction mechanisms in Malaysia water," Arab. J. Geosci., vol. 9, no. 20, 2016.

[16] H. Ghasemi, M. Zare, Y. Fukushima, and K. Koketsu, "An empirical spectral ground-motion model for Iran," $J$. Seismol., vol. 13, no. 4, pp. 499-515, 2009.

[17] G. G. Amiri, A. Mahdavian, and F. M. Dana, “Attenuation relationships for Iran,” J. Earthq. Eng., vol. 11, no. 4, pp. 469-492, 2007.

[18] A. A. Nowroozi, "Attenuation relations for peak horizontal and vertical accelerations of earthquake ground motion in Iran: a preliminary analysis," Engineering, vol. 7, no. 2, pp. 109-128, 2005.

[19] R. SIGBJORNSSON and A. S. ELNASHAI, "Hazard Assessment of Dubai, United Arab Emirates, for Close and Distant Earthquakes," J. Earthq. Eng., vol. 10, no. 5, pp. 749-773, 2006.

[20] D. M. Joyner, W. B., \& Boore, "Measurement, characterization, and prediction of strong ground motion," Earthq. Eng. Soil Dyn. II, Proc. Am. Soc. Civ. Eng. Geotech. Eng. Div. Spec. Conf. Park City, Utah, pp. 43-102.

[21] H. Hamzehloo and M. Mahood, "Ground-motion attenuation relationship for East Central Iran," Bull. Seismol. Soc. Am., vol. 102, no. 6, pp. 2677-2684, 2012.

[22] D. M. Joyner, W. B., \& Boore, Prediction of earthquake response spectra. 1982. 